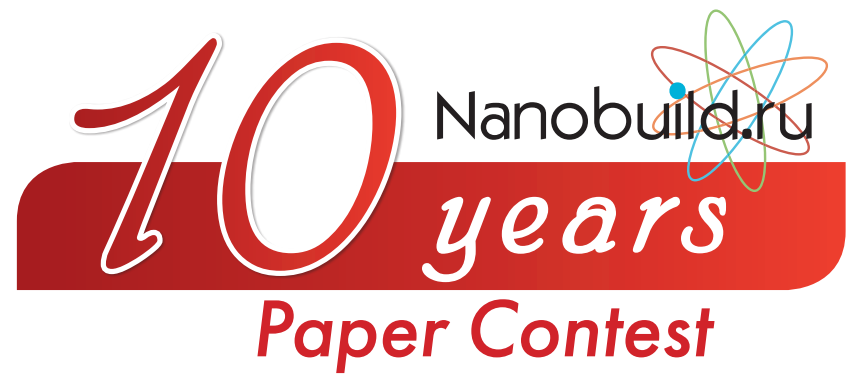

UDC 69.001.5

Author: MALKIN Polad, Ph.D., Senior Researcher, Ben-Gurion University in the Negev, Israel, P.O.B. 653 Beer-Sheva, 841050,1 Israel, polad.malkin@gmail.com

\title{
WASTEWATER TREATMENT FROM HEAVY METAL IONS USING NANOACTIVATED COMPLEXES OF NATURAL ZEOLITE AND DIATOMITE
}

\section{ExTEnded Abstract:}

Despite the wide practical use of sorption methods and complexones in treatment of industrial wastewater, some problems are still to be solved in this field. These are the most significant: insufficient sorption capacity of materials, lack of reliable methods for regenerating sorbents and resource-saving ecology friendly treatment technologies with the use of sorbents as well as methods of utilization of heavy metals from waste by complex formation.

An important factor affecting the behavior of heavy metals in the soil is the medium acidity. With a neutral and slightly alkaline reaction of the medium, hardly soluble compounds are formed: hydroxides, sulphides, phosphates, carbonates, and oxalates of heavy metals. When acidity increases the reverse process runs in the soil: hardly soluble compounds become more mobile, while mobility of many heavy metals increases. However, the effect of soil acidity on mobility of heavy metals is ambiguous. Although mobility of many heavy metals decreases with increasing $\mathrm{pH}$ of the medium (for example, Fe, $\mathrm{Mn}, \mathrm{Zn}$, Co, etc.), there are a number of metals whose mobility increases with soil neutralization. These include molybdenum and chromium, which are able to form soluble salts in a weak- 
ly acidic and alkaline medium. In addition, heavy metals such as mercury and cadmium are able to maintain mobility in an alkaline medium through formation of complex compounds with organic matter in soils. Heavy metals interact with a solid phase of the soil by mechanisms of specific and nonspecific adsorption.

In this article, a technique of wastewater treatment from heavy metal ions using nanoactivated complexes of natural zeolite and diatomite is proposed. This technique can reduce significant costs in preparation of raw materials and subsequent chemical modification of them. Technological solutions aimed at disposal and recycling of industrial wastewater have been proposed. These solutions make it possible to obtain the water treated to the necessary standard impurity content and reuse it in the technological process.

Key words: zeolite, diatomite, wastewater, heavy metal ions, ecology, water treatment, water treatment method, nanoactivated complex, natural sorbent, nanotechnologies.

DOI: dx.doi.org/10.15828/2075-8545-2018-10-2-21-41

MACHINE-READABLE INFORMATION ON CC-LICENSES (HTML-CODE) IN METADATA OF THE PAPER

$<$ a rel="license" href="http://creativecommons.org/licenses/by/4.0/"><img alt="Creative Commons License" style="borderwidth:0" src="https://i.creativecommons.org/l/by/4.0/88x31.png" $/></ \mathrm{a}><$ br $/><$ span xmlns:dct="http://purl.org/dc/ terms/" href="http://purl.org/dc/dcmitype/Text" property="dct:title" rel="dct:type" $>$ Wastewater treatment from heavy metal ions using nanoactivated complexes of natural zeolite and diatomite. $</$ span $>$ by $<$ a xmlns:cc="http://creativecommons. org/ns\#" href="Nanotehnologii v stroitel'stve = Nanotechnologies in Construction. 2018, Vol. 10, no. 2, pp. 21-41. DOI: dx.doi. org/10.15828/2075-8545-2018-10-2-21-41." property="cc:attributionName" rel="cc:attributionURL">Malkin P. $</$ a $>$ is licensed under a $<$ a rel="license" href="http://creativecommons.org/licenses/by/4.0/" $>$ Creative Commons Attribution 4.0 International License $</ \mathrm{a}>$. $<\mathrm{br} />$ Based on a work at $<$ a xmlns:dct="http://purl.org/dc/terms/" href=" http://nanobuild.ru/ en_EN/nanobuild-2-2018/" rel="dct:source" > http://nanobuild.ru/en_EN/nanobuild-2-2018/</a $>$. $<$ br $/>$ Permissions beyond the scope of this license may be available at $<$ a xmlns:cc="http://creativecommons.org/ns\#" href="polad.malkin@gmail.com" rel="cc:morePermissions" $>$ polad.malkin@gmail.com $</ a>$.

ccording to the World Health Organization, human diseases caused by consumption of low-quality water can account for up to $80 \%$ of the total number of health problems. In general, more than half of the world population consume low-quality water, and thus every third inhabitant is endangered by gastrointestinal diseases. Economic damage from morbidity of the population using low-quality water virtually can not 
be measured to the full extent due to specifics of the problem and incomplete initial data. Nevertheless, one can say with certainty that this component predominates in the total amount of damage from pollution of water sources.

Sewage of enterprises contain oil products, heavy metal ions, and many different chemical compounds. Harmful chemical elements and substances enter water bodies worsening their sanitary condition, which requires thorough water treatment before using it for household and drinking purposes and for some industrial purposes [1-7].

Often, these methods involve natural sorbents with subsequent mechanical grinding, thermal and/or chemical modification to obtain high rate of adsorption at the output. The chemical modification must be chosen for the different types of contamination separately which also increases the treatment process cost. The developed method allows creating a nanoactivated complex of natural zeolite and diatomite. Its production is tens of times cheaper than that of the existing methods in the absence of costs for expensive grinding, expensive chemical components and chemical modification process.

The environmental problems of wastewater treatment are considered in papers of Alekseev M.I., Vinogradov S.S., Gubanov L.N., Ilyin Yu.A., Evilevich A.Z., Zainullin Kh.N., Zapolsky A.K., Koganovsky A.M., Kudryavtsev V.N., Ksenofontov B.S., Naidenko V.V., Palgunov P.P., Smirnov A.D., Tarasevich I.Yu., Yakovlev S.V. and others.

In this article, a technique of wastewater treatment from heavy metal ions using nanoactivated complexes of natural zeolite and diatomite is proposed. This technique can reduce significant costs in preparation of raw materials and its subsequent chemical modification. Technological solutions are proposed for disposal and recycling of industrial wastewater allowing obtaining water treated to the necessary regulatory water content of impurities and returning it to the process cycle. The uniqueness of the method and techniques is in the use of nanoactivated natural sorbents for treatment of both ion-exchange water, and also natural water from heavy metal ions that pollute it.

Some natural materials are quite active in the natural state, but most of them are advisable to activate by chemical or thermal means to increase and adjust their porous structure, and change the chemical nature of the surface [8-11]. Various methods of modifying natural materials, includ- 
ing activated carbons, lead to production of sorbents with specific sorption properties to a wide range of organic and inorganic substances [12-16]. A new field of application of nanomaterials based on carbon and inorganic nanostructures is developing especially intensively [17-20]. As a result, sorbents with a porous structure different from the original mineral are obtained, combining the useful properties of the initial material and synthetic sorbents [21, 22].

One of the most promising methods of treating natural and waste water is sorption on various natural materials, to re-use treated water in closed water systems of enterprises. The increase in the scale of application of natural sorbents is due to the fact that, with a developed specific surface, they have good sorption properties and are ten times cheaper than synthetic ones. In this regard, their technological application is simplified often excluding the regeneration stage.

The simplest method which does not require additional reagents and complex hardware design, is thermal modification of various materials. The obtained materials are characterized by increased sorption properties with respect to various organic and inorganic substances.

The main problem of modern technological systems of application is the development of environmentally safe technologies with the most closed cycle and the minimum amount of waste. The current situation in this field of research has necessitated the improvement of sorption technologies and selective processes for treatment of contaminated solutions and process fluids for the integrated solution of resource-saving and environmental problems. As a result of target of studies of a wide range of sorption materials in relation to wastewater treatment, the processes of adsorption of oil products and heavy metal ions on natural sorbents and their analogs have been further developed.

Often, these methods involve natural sorbents with subsequent mechanical grinding, thermal and/or chemical modification to obtain high rate of adsorption at the output. The chemical modification must be chosen for the different types of contamination separately which also increases the treatment process cost. The developed method allows creating a nanoactivated complex of natural zeolite and diatomite. Its production is tens of times cheaper than that of the existing methods in the absence of costs for expensive grinding, expensive chemical components and chemical modification process. 
In this work, a sorbent for water treatment from heavy metal ions is produced from a natural zeolite and diatomite nanoactivated using an ultrasonic through-flow disperser in the following ratios of components (wt. \%): diatomite $-20-30$, zeolite - the rest. The resulting sorbent allows trapping arsenic ions of different valences, cadmium, cesium, copper, zinc, nickel, lead, chromium, sulfate ions, chloride ions, and others.

The main difference of the result in the output sorbent of this method is an expanded list of heavy metal ions captured to a high degree of treatment, and also the most concentration of contamination of effectively treated water which is greater than $20 \mathrm{mg} / 1$, i.e., 3-4 times higher than that of most of the previously proposed methods. Furthermore, when using the proposed sorbent obtained in this method, no metal ions release, and absorption of metal ions actively continues. These technical results are achieved because a sorbent for water treatment from heavy metals ions is produced from natural zeolite and diatomite nanoactivated in the throughflow ultrasonic disperser.

Moisture is separated by passing the slurry through a separator which also divides the resulting prepared sorbent into fractions followed by calcination for 4 hours at $250-300^{\circ} \mathrm{C}$. Thus, the proposed technique makes it possible to obtain fractions of nanoactivated natural sorbent with particle size of classes: $0.5-1 \mathrm{~nm}, 0.005-0.01$ microns, $0.5-1$ micron. Reduction in sizes is done by ultrasonic cavitation in the flow regime; the percentage ratio of the mass fraction of solids to water is 70:30.

The sorbent samples of nanoactivated complexes of natural zeolites and diatomites were tested for the adsorption capacity with respect to heavy metal ions as follows. Absorption of the specified heavy metal ions was studied from model solutions at a concentration of $20 \mathrm{mg} / \mathrm{l} .100 \mathrm{~g}$ of the sorbent was placed in $10 \mathrm{l}$. of the test solution in the $\mathrm{pH}$ range of 5-7 and stirred with a mechanical submersible stirrer for 30 minutes. The solution was then settled for 20 minutes and analyzed by stripping voltammetry for residual content of heavy metal ions. The concentration was evaluated by adding the standard solution of the specified heavy metal ions with a concentration of $20 \mathrm{mg} / \mathrm{l}(50 \mathrm{ml})$. The minimum detectable concentration was $0.001 \mathrm{mg} / \mathrm{l}$. The sorption percentage was calculated while taking the initial concentration of heavy metal ions as $100 \%$.

Depending on the data obtained, the degree of extraction was determined to determine the dynamic characteristics of the adsorption process. 
Experimentally, the amount of adsorption (A) of contaminants and the degree of extraction $(\alpha)$ were calculated as follows:

$$
\begin{aligned}
& \mathrm{A}=\left(\mathrm{C}_{\text {init }}-\mathrm{C}\right) \cdot \mathrm{V}_{\text {sol }} / \mathrm{m}_{\text {sorb }} \\
& \alpha(\%)=\left(\mathrm{C}_{\text {init }}-\mathrm{C}\right) \cdot 100 / \mathrm{C}_{\text {init }},
\end{aligned}
$$

where $\mathrm{C}_{\text {init }}$ and $\mathrm{C}$ are the initial and the equilibrium concentration of heavy metal ions in the solution; $\mathrm{V}_{\text {sol }}$ - solution volume; $\mathrm{m}_{\text {sorb }}$ - sorbent mass.

Data on the sorption capacity of the obtained sorbent samples with different concentration of diatomite and zeolite is given in Table 1.

Table 1

Sorption capacity of the obtained sorbent samples with different concentration of diatomite and zeolite

\begin{tabular}{|c|c|c|}
\hline Zeolite, \% of content & Diatomite, \% of content & $\alpha$ (\%), sorption \\
\hline 100 & 0 & $62,3 \pm 0,5$ \\
\hline 95 & 5 & $71 \pm 0,5$ \\
\hline 90 & 10 & $89 \pm 0,5$ \\
\hline 85 & 15 & $90,1 \pm 0,5$ \\
\hline 80 & 20 & $97,8 \pm 0,5$ \\
\hline 75 & 25 & $100 \pm 0,5$ \\
\hline 70 & 30 & 100 \\
\hline 65 & 35 & $96 \pm 0.5$ \\
\hline
\end{tabular}

As we can see from the results of experiments, the best results are shown by samples of diatomite in concentrations ranging from $20-30 \%$. The minimum absorption is observed with a decrease in the proportion of diatomite less than $20 \%$, but also with its significant increase of more than $30 \%$.

The experiment showed that there is a degree of extraction ratio on the sorbent sample processing temperature. The data is given in Table 2 and graphically in Fig. 1. 
Degree of extraction ratio on the sorbent sample processing temperature

\begin{tabular}{|c|c|c|c|c|c|c|c|c|c|}
\hline $\mathrm{T},{ }^{\circ} \mathrm{C}$ & 100 & 150 & 200 & 250 & 300 & 350 & 400 & 500 & 600 \\
\hline$\alpha, \%$ & 83,5 & 91,7 & 95,8 & 98,6 & 99,4 & 97,1 & 91,8 & 85,1 & 83,7 \\
\hline
\end{tabular}

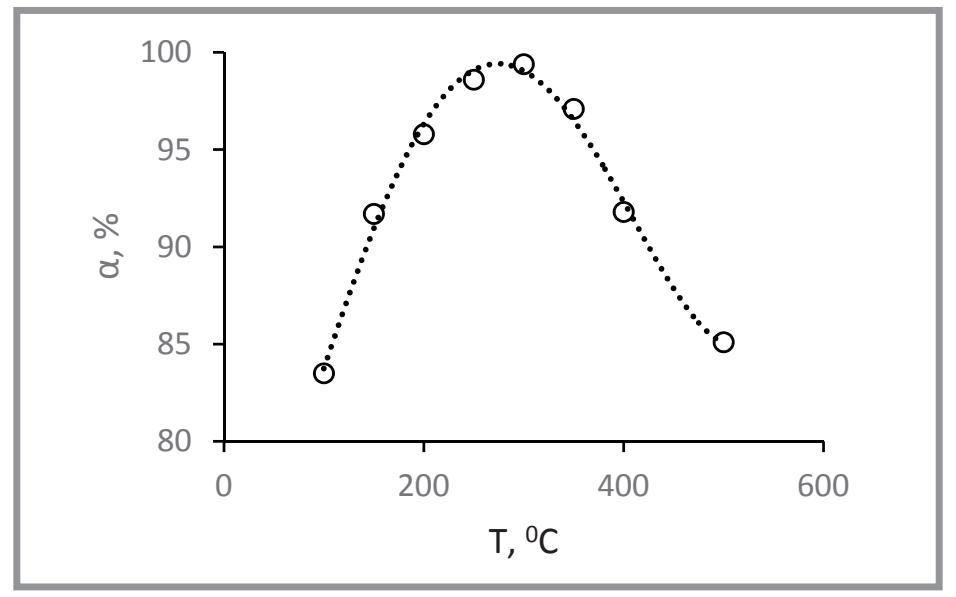

Fig. 1. Degree of extraction ratio on the sorbent sample processing temperature

By analyzing the data obtained it can be concluded on the best sorption properties of the obtained sample at a temperature of $250-300^{\circ} \mathrm{C}$. All samples of various concentrations of diatomite and zeolite were tested at different temperatures. We can say that there is a dependence on the sorbent heating time and $\mathrm{pH}$ of the solution being treated. Optimal time of the sorbent heat treatment is from 2-4 hours, further heating does not impair the degree of treatment. The data obtained are well correlated with the results [23-26].

Is known to use zeolite-containing sorbent treated by calcination at a temperature of $250^{\circ} \mathrm{C}$ for $2-4$ hours for water treatment from metal ions [27], but the disadvantage of this invention is the low sorbent efficiency. Also known are methods where a chemically modified zeolite is used [28] and [29]. The disadvantages of these methods include a narrow list of elements to be treated, as well as low sorbent efficiency and high cost of production. 
The developed method allows obtaining a high degree of treatment at minimal cost for preparation of raw materials compared to the known methods. The most efficient modes for the sorbent production by the above method were obtained.

\section{References:}

1. Problemy zagrjaznenija okruzhajushhej sredy i toksikologii [Problems of environmental pollution and toxicology]. Trans. from English. Ed. by J. Ware. Moscow: Mir, 1993. 192 p. (In Russian).

2. Telitchenko M.M., Ostroumov S.A. Vvedenie v problemy biohimicheskoj jekologii: biotehnologija, sel'skoe hozjajstvo, ohrana sredy. [Introduction to the problems of biochemical ecology: Biotechnology, agriculture, environmental protection]. Moscow: Science, 1990. 285 p. (In Russian).

3. Chernyaev A.M., Dalkov M.P., Rozenberg G.S. Voda Rossii. Rechnye bassejny [Water of Russia. River basins]. Ekaterinburg: AQUA-PRESS, 2000. 536 p. (In Russian).

4. Vinogradov S.S. Jekologicheski bezopasnoe gal'vanicheskoe proizvodstvo [Environmentally safe galvanic production]. Moscow: Globus, 1998. 302 p. (In Russian).

5. Vinogradov S.S. Organizacija gal'vanicheskogo proizvodstva. Oborudovanie, raschet proizvodstva, normirovanie [Organization of galvanic production. Equipment, calculation of production, rationing]. Moscow: Globus, 2005. 368 p. (In Russian).

6. Frog B.N., Levchenko A.P. Vodopodgotovka [Water treatment]. Moscow: Moscow State University, 1996. 680 p. (In Russian).

7. Alekseev Yu.V. Tjazhelye metally v pochvah i rastenijah [Heavy metals in soils and plants]. Leningrad.: Agropromizdat, 1987. 142 p. (In Russian).

8. Lukaszczyk, J., Lekawska E., Lunkwitz K., Petzold G. Sorbents for Removal Surfactants from Aqueous Solutions. Surface Modification of Natural Solids to Enhance Sorption Ability. J. Appl. Pol. Sci. 2004. № 2. P. 1510-1515.

9. Wan Ngah W.S., Hanafiah M.A. Removal of heavy metal ions from wastewater by chemically modified plant wastes as adsorbents: A Review. Bioresource. Technol. 2008. V. 99. P. 3935-3948.

10. Unuabonah E.I., Adebowale K.O., Olu-Owolabi B.I. Adsorption of $\mathrm{Pb}$ (II) and $\mathrm{Cd}$ (II) from aqueous solutions onto sodium tetraborate-modified Kaolinite clay: Equilibrium and thermodynamic studies. Hydrometallurgy. 2008. V. 93. P. 1-9. 
11. Jiang, $M$., Wang Q., Jin $X$., Chen $Z$. Removal of $\mathrm{Pb}(\mathrm{II})$ from aqueous solution using modified and unmodified kaolinite clay. J. Hazard. Matter. 2009. V. 170. P. 332339.

12. Özdemir, G., Yapar S. Adsorption and desorption behavior of copper ions on Namontmorillonite: Effect of rhamnolipids and pH. J. Hazard. Matter. 2009. V. 166. P. 1307-1313.

13. Xu, H., Yang L., Wang P., Liu Y. Kinetic research on the sorption of aqueous lead by synthetic carbonate hydroxyapatite. J. Environ. Manage. 2008. V. 86. P. 319328.

14. Nadeem, M., Shabbir M., Abdullah M.A. Sorption of cadmium from aqueous solution by surfactant-modified carbon adsorbents. Chem. Eng. J. 2009. V. 148. P. 365-370.

15. Di Natale F., Erto A., Lancia A., Musmarra D. Experimental and modelling analysis of $\mathrm{As}(\mathrm{V})$ ions adsorption on granular activated carbon. Water. Res. 2008. V. 42. P. 2007-2016.

16. Azizian, S., Haerifar M., Bashiri H. Adsorption of methyl violet onto granular activated carbon: Equilibrium, kinetics and modeling. Chem. Eng. J. 2009. V. 146. P. 36-41.

17. Rao, G., Lu C., Su F. Sorption of divalent metal ions from aqueous solution by carbon nanotubes: A Review. Sep. Purif. Technol. 2007. V. 58. P. 224-231.

18. Zhang, L., Huang T., Zhang M., Guo X. Studies on the capability and behavior of adsorption of thallium on nano- $\mathrm{Al}_{2} \mathrm{O}_{3}$. J. Hazard. Matter. 2008. V. 157. P. 352-357.

19. Debnath, S., Ghosh U. Nanostructured hydrous titanium (IV) oxide: Synthesis, characterization and Ni (II) adsorption behavior. Chem. Eng. J. 2009. V. 152. P. 480-491.

20. Gao, Z., Bandosz T., Zhao Z., Han M. Investigation of factors affecting adsorption of transition metals on oxidized carbon nanotubes. J. Hazard. Matter. 2009. V. 167. P. 357-365.

21. Lisichkin G.V. Modificirovannye kremnezemy v sorbcii, katalize i hromatografii [Modified silica in sorption, catalysis and chromatography]. Moscow: Khimija, 1986. 556 p. (In Russian).

22. Lisichkin G.V., Fadeev A.Yu., Serdan A.A.et. al. Himija privityh poverhnostnyh soedinenij [Chemistry of chemically bonded surface compounds]. Moscow: Fizmatlit, 2003. 589 p. 23. (In Russian).

23. Klimov E.S., Buzaeva M.V. Prirodnye sorbenty i kompleksony v ochistke stochnyh vod [Natural sorbents and complexons in wastewater treatment]. Ulyanovsk: UlSTU, 2011. 201 p. (In Russian). 
24. Slesarenko F.A. Fiziko-himicheskie issledovanija prirodnyh sorbentov[ Physicochemical studies of natural sorbents]. Saratov: Min. of Education of the RSFSR. 1968. 102 p. (In Russian).

25. Khalilov E.N., Bagirov R.A. Prirodnye ceolity, ih svojstva, proizvodstvo i primenenie [Natural zeolites, their properties, production and application]. Baku-Berlin, 2002. 347 p. (In Russian).

26. Keltsev N.V. Osnovy adsorbcionnoj tehniki [Basics of adsorption equipment]. Moscow: Khimija, 1984. 591 p. (In Russian).

27. Patent of the Russian Federation 96112598/25, 25.06.1996. Method of absorption water treatment. Patent of Russia No. 21111171. 20.05.1998. Konyukhova T.P.; Chupryna T.N.; Nagaeva S.Z.; Kikilo D.A.; Mikhaylova O.A.; Luchkin G.S.; Distanov U.G .; Kharisov Yu.G.

28. Patent of the Russian Federation 2000121520/04, 10.08.2000. Method of obtaining organomineral sorbents. Patent of Russia No. 2184607. 10.07.2002. Shapkin N.P.

29. Patent of the Russian Federation 2013152455A, 10.06.2015. The method of detoxification of wastewater contaminated with arsenic salts. Patent of Russia No. 2562495. 10.09.2015. Kan V.M., Konovalov A.S., Taran D.O., Bobrov A.N., Butyrin M.V., Stom D.I.

Dear Colleagues!

THE REFERENCE TO THIS PAPER HAS THE FOLLOWING CITATION FORMAT:

Malkin $P$. Wastewater treatment from heavy metal ions using nanoactivated complexes of natural zeolite and diatomite. Nanotehnologii v stroitel'stve = Nanotechnologies in Construction. 2018, Vol. 10, no. 2, pp. 21-41. DOI: dx.doi. org/10.15828/2075-8545-2018-10-2-21-41. 


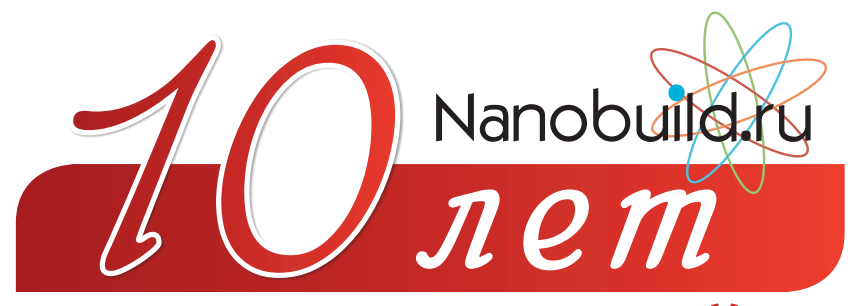

конкурс статей

удК 69.001.5

Автор: МАЛКИН Полад, д.ф.-м.н., старший научный сотрудник, Университет Бен-Гуриона

в Негеве, г. Беэр-Шева, Израиль; п/я 653, г. Беэр Шева, Израиль, 8410501,

polad.malkin@gmail.com

\section{ОЧИСТКА СТОЧНЫХ ВОД ОТ ИОНОВ ТЯЖЕЛЫХ МЕТАЛЛОВ С ПОМОЩЬЮ НАНОАКТИВИРОВАННЫХ КОМПЛЕКСОВ ПРИРОДНОГО ЦЕОЛИТА И ДИАТОМИТА}

\section{АННОТАЦИЯ К СТАТЬЕ (АВТОРСКОЕ РЕЗЮМЕ, РЕФЕРАТ):}

Несмотря на широкое практическое использование сорбционных методов и комплексонов в очистке производственных сточных вод, в этой области существует ряд проблем. К наиболее существенным относятся следующие: недостаточная сорбционная емкость материалов, отсутствие надежных способов регенерации сорбентов, ресурсосберегающих экологизированных технологий очистки с использованием сорбентов, способов утилизации тяжелых металлов из отходов комплексообразованием.

Важным фактором, влияющим на поведение тяжелых металлов в почве, является кислотность среды. При нейтральной и слабощелочной реакции среды образуются труднорастворимые соединения: гидроксиды, сульфиды, фосфаты, карбонаты и оксалаты тяжелых металлов. При возрастании кислотности в почве идет обратный процесс - труднорастворимые соединения переходят в более подвижные, при этом повышается подвижность многих тяжелых металлов. Однако действие кислотности почв на подвижность тяжелых металлов неоднозначно. Хотя при возрастании рН среды подвижность многих тяжелых металлов снижается (например, Fe, Mn, Zn, Cо и др.), имеет- 
ся ряд металлов, подвижность которых при нейтрализации почвы возрастает. К ним относятся молибден и хром, которые способны в слабокислой и щелочной среде образовывать растворимые соли. Кроме того, такие тяжелые металлы, как ртуть и кадмий, способны сохранять подвижность в щелочной среде за счет образования комплексных соединений с органическим веществом почв. С твердой фазой почвы тяжелые металлы взаимодействуют по механизмам специфической и неспецифической адсорбции.

В статье предложена методика очистки сточных вод от ионов тяжелых металлов с помощью наноактивированных комплексов природного цеолита и диатомита. Данная методика позволяет сократить значительные издержки в подготовке сырья и последующей его химической модификации. Предложены технологические решения по обезвреживанию и утилизации производственных сточных вод и позволяющие получать очищенную до необходимого нормативного содержания примесей воду и возвращать ее в технологический цикл.

Ключевые слова: цеолит, диатомит, сточные воды, ионы тяжелых металлов, экология, очистка воды, метод очистки воды, наноактивированный комплекс, природный сорбент, нанотехнологии.

DOI: dx.doi.org/10.15828/2075-8545-2018-10-2-21-41

МАШИНОЧИТАЕМАЯ ИНФОРМАЦИЯ О СС-ЛИЦЕНЗИИ В МЕТАДАННЫХ СТАТЬИ (HTML-КОД):

$<$ a rel="license" href="http://creativecommons.org/licenses/by/4.0/"><img alt="Лицензия Creative Commons" style="borderwidth:0" src="https://i.creativecommons.org/l/by/4.0/88x31.png" / ></a $><$ br $/>$ Произведение «<span xmlns:dct="http:// purl.org/dc/terms/" href="http://purl.org/dc/dcmitype/Text" property="dct:title" rel="dct:type">Очистка сточных вод от ионов тяжелых металлов с помощью на- ноактивированных комплексов природного цеолита и диатомита $</$ span $>$ " созданное автором по имени $<$ a xmlns:cc="http://creativecommons.org/ns\#" href="Нанотехнологии в строительстве. 2018. - Toм 10, № 2. - C. 21-41. - DOI: dx.doi. org/10.15828/2075-8545-2018-10-2-21-41." property="cc:attributionName" rel="cc:attributionURL"> Малкин П. </a >, публикуется на условиях <a rel="license" href="http://creativecommons. $\mathrm{org} / \mathrm{licenses} / \mathrm{by} / 4.0 / ">$ лицензии Creative Commons C указанием авторства 4.0 Всемирная $</ \mathrm{a}>$. $<\mathrm{br} />$ Основано на произведении с <a xmlns:dct="http://purl.org/dc/terms/" href="http://nanobuild.ru/ru_RU/nanobuild-2-2018/" rel="dct:source">http://nanobuild.ru/ru_RU/nanobuild-2-2018/</a >. $<$ br / > Разрешения, выходящие за рамки данной лицензии, могут быть доступны на странице <a xmlns:cc="http://creativecommons.org/ns\#" href="polad.malkin@gmail.com" rel="cc:morePermissions" $>$ polad.malkin@gmail.com $</ a>$.

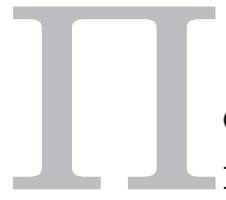

о мнению Всемирной организации здравоохранения, заболевания человека, вызванные потреблением некачественной воды, могут составлять до $80 \%$ от общего числа проблем со здоровьем. В це- 
лом в мире более половины населения потребляет недоброкачественную воду, в результате чего каждый третий житель подвергается угрозе кишечно-желудочных заболеваний. Экономический ущерб от заболеваемости населения при употреблении некачественной воды практически не может быть измерен в полной мере ввиду специфики проблемы и неполноты исходных данных. Тем не менее, можно с уверенностью говорить о преобладании этой составляющей в общей сумме ущерба от загрязнения водных источников.

Сточные воды предприятий содержат нефтепродукты, ионы тяжелых металлов, множество различных химических соединений. Вредные химические элементы и вещества попадают в водоемы, ухудшая их санитарное состояние, в связи с чем необходима глубокая очистка воды перед использованием ее в хозяйственно-питьевых и некоторых промышленных целях [1-7].

С ростом технологических производств остро встает вопрос по очистке отработанной воды, которая содержит нефтепродукты, ионы тяжелых металлов и множество различных химических соединений. На сегодняшний день существует достаточно много эффективных технологических методов по очистке таких загрязнений, но все эти методы имеют четкую зависимость степени очистки от понесенных затрат на этот процесс, поэтому в реальном секторе экономики данные методы используются избирательно или частично ввиду существенной стоимости данных методов.

Экологическим проблемам очистки сточных вод посвящены работы Алексеева М.И., Виноградова С.С., Губанова Л.Н., Ильина Ю.А., Евилевича А.З., Зайнуллина Х.Н., Запольского А.К., Когановского А.М., Кудрявцева В.Н., Ксенофонтова Б.С., Найденко В.В., Пальгунова П.П., Смирнова А.Д., Тарасевича И.Ю., Яковлева С.В. и других.

В данной работе предложена методика очистки сточных вод от ионов тяжелых металлов с помощью наноактивированных комплексов природного цеолита и диатомита. Данная методика позволяет сократить значительные издержки в подготовке сырья и последующей его химической модификации. Предложены технологические решения по обезвреживанию и утилизации производственных сточных вод и позволяющие получать очищенную до необходимого нормативного содержания примесей воду и возвращать ее в технологический цикл. Уникальность продолженного метода и приемов по использованию наноактивирован- 
ных природных сорбентов в том, что они могут быть использованы для очистки не только ионно-обменной воды, но и природной воды от загрязняющих ее ионов тяжелых металлов.

Некоторые природные материалы достаточно активны в естественном состоянии, но большую часть из них целесообразно активировать химическим или термическим способом для увеличения и регулирования их пористой структуры, изменения химической природы поверхности [8-11]. Различные способы модифицирования природных материалов, в том числе активированных углей, приводят к получению сорбентов, обладающих специфическими сорбционными свойствами к широкому спектру органических и неорганических веществ [12-16]. Особенно интенсивно развивается новая область применения наноматериалов на основе углеродных и неорганических наноструктур [17-20]. В результате получаются сорбенты с отличной от исходного минерала пористой структурой, сочетающие в себе полезные свойства исходного материала и синтетических сорбентов [21,22].

Одним из наиболее перспективных методов очистки природных и сточных вод является сорбция на различных природных материалах, что позволяет повторно использовать очищенную воду в замкнутых системах водного хозяйства предприятий. Увеличение масштабов применения природных сорбентов обусловлено тем, что при развитой удельной поверхности они обладают хорошими сорбирующими свойствами и в десятки раз дешевле синтетических. В связи с этим упрощается их технологическое применение, часто исключается стадия регенерации.

Наиболее простым способом, не требующим дополнительных реагентов и сложного аппаратного оформления, является термическое модифицирование различных материалов. Полученные материалы характеризуются повышенными сорбционными свойствами по отношению к различным органическим и неорганическим веществам.

Основной проблемой современных технологических систем применения является разработка экологически безопасных технологий с максимально замкнутым циклом и минимальным количеством отходов. Сложившаяся в настоящее время ситуация в этой области исследований вызвала необходимость совершенствования сорбционных технологий и селективных процессов очистки загрязненных растворов и технологических жидкостей для комплексного решения ресурсосберегающих 
и экологических проблем. В результате направленных исследований широкого спектра сорбционных материалов применительно к очистке сточных вод получили дальнейшее развитие процессы адсорбции нефтепродуктов и ионов тяжелых металлов на природных сорбентах и их аналогах.

Зачастую все эти методы используют природные сорбенты с последующим механическим измельчением, термической и/или химической модификацией, чтобы получить на выходе высокий показатель адсорбции, при этом нужно подбирать химическую модификацию для различных видов загрязнения отдельно, что так же повышает стоимость процесса очистки. Разработанный метод позволяет создать наноактивированный комплекс природного цеолита и диатомита, процесс производства которого в десятки раз дешевле ранее существующих методов, в виду отсутствия затрат на дорогостоящий размол, на дорогостоящие химические компоненты и процесс химической модификации.

В данной работе сорбент для очистки воды от ионов тяжелых металлов получают из природного цеолита и диатомита, наноактивированных при помощи ультразвукового проточного диспергатора, при следующем соотношении компонентов, мас. \%: диатомит 20-30, цеолит - остальное. Получаемый сорбент позволяет улавливать ионы мышьяка разной валентности, кадмия, цезия, меди, цинка, никеля, свинца и хрома, сульфата ионов, хлорида ионов и др.

Основным отличием получаемого результата в выходном сорбенте данного метода является расширение списка ионов тяжелых металлов, улавливаемых до высокой степени очистки, а также наибольшая концентрация загрязнения эффективно очищаемой воды, которая составляет более, чем 20 мг/л, т.е. выше, чем у большинства ранее предложенных методов, в 3-4 раза. Кроме того, при использовании предложенного сорбента, получаемого в данном методе, не происходит высвобождение ионов металлов, а процесс поглощения ионов металлов активно продолжается.

Указанные технические результаты достигаются тем, что сорбент для очистки воды от ионов тяжелых металлов получается из природного цеолита и диатомита, наноактивированных в проточном ультразвуковом диспергаторе, после чего далее производится отделение влаги путем пропускания суспензии через сепаратор, который также делит 
полученный подготовленный сорбент на фракции, после его прокаливают в течение 4 часов при температуре $250-300^{\circ} \mathrm{C}$. Таким образом, предложенная технология дает возможность получать фракции наноактивированного природного сорбента с крупностью частиц классов: 0,5-1 нм, 0,005-0,01 мкм, 0,5-1 мкм. Измельчение производится при ультразвуковой кавитации в проточном режиме, процент соотношения по массовой доле сухого вещества и воды - 70:30.

Испытания полученных образцов сорбента наноактивированных комплексов природных цеолитов и диатомита на адсорбционную способность по отношению к ионам тяжелых металлов проводили следующим образом. Исследование поглощения заданных ионов тяжелых металлов проводили из модельных растворов с концентрацией 20 мг/л. На 100 г сорбента - 10 л модельного раствора в пределах $\mathrm{pH}$ 5-7, перемешивали механической мешалкой погружного типа в течение 30 мин. Затем раствор отстаивали в течение 20 мин и анализировали методом инверсионной вольтамперометрии на остаточное содержание ионов тяжелых металлов. Оценку концентрации проводили методом добавок стандартного раствора заданных ионов тяжелых металлов с концентрацией 20 мг/л (в количестве 50 мл). Минимально определяемая концентрация составляла 0,001 мг/л. Процент сорбции был вычислен при принятии за 100\% исходной концентрации заданных ионов тяжелых металлов.

В зависимости от полученных данных определяли степень извлечения для определения динамических характеристик процесса адсорбции. Экспериментально величину адсорбции (А) загрязняющих веществ и степень извлечения $(\alpha)$ вычисляли по уравнениям:

$$
\begin{aligned}
& \mathrm{A}=\left(\mathrm{C}_{\text {исх }}-\mathrm{C}\right) \cdot \mathrm{V}_{\mathrm{p}-\mathrm{pa}} / \mathrm{m}_{\text {сорб }}, \\
& \alpha(\%)=\left(\mathrm{C}_{\text {исх }}-\mathrm{C}\right) \cdot 100 / \mathrm{C}_{\text {исх }},
\end{aligned}
$$

где $\mathrm{C}_{\text {исх }}$ и $\mathrm{C}$ - исходная и равновесная концентрация ионов тяжелых металлов в растворе; $\mathrm{V}_{\mathrm{p}-\mathrm{pa}}$ - объем раствора; $\mathrm{m}_{\text {сорб }}$ - масса сорбента.

Данные по сорбционной способности полученных образцов сорбента с разным содержанием концентрации диатомита и цеолита приведены в табл. 1. 
таблииа 1

Абсорбционная способность полученных образцов сорбента при различных концентрациях диатомита и цеолита

\begin{tabular}{|c|c|c|}
\hline Цеолит, \% содержания & Диатомит, \% содержания & $\alpha(\%)$, сорбции \\
\hline 100 & 0 & $62,3 \pm 0,5$ \\
\hline 95 & 5 & $71 \pm 0,5$ \\
\hline 90 & 10 & $89 \pm 0,5$ \\
\hline 85 & 15 & $90,1 \pm 0,5$ \\
\hline 80 & 20 & $97,8 \pm 0,5$ \\
\hline 75 & 25 & $100 \pm 0,5$ \\
\hline 70 & 30 & 100 \\
\hline 65 & 35 & $96 \pm 0,5$ \\
\hline
\end{tabular}

Как мы можем увидеть из результатов экспериментов, наилучшими результатами обладают образцы в концентрациях диатомита от 20-30\%, наименьшая абсорбция наблюдается при снижении доли диатомита менее $20 \%$, но и также при значительном его увеличении свыше $30 \%$.

Исходя из результатов экспериментов, можно сделать вывод о наличии зависимости степени извлечения от температуры обработки образцов сорбента, данные приведены в табл. 2 и в графическом виде на рис. 1.

Таблица 2

Зависимость степени извлечения от температуры обработки образцов сорбента

\begin{tabular}{|c|c|c|c|c|c|c|c|c|c|}
\hline $\mathrm{T},{ }^{\circ} \mathrm{C}$ & 100 & 150 & 200 & 250 & 300 & 350 & 400 & 500 & 600 \\
\hline$\alpha, \%$ & 83,5 & 91,7 & 95,8 & 98,6 & 99,4 & 97,1 & 91,8 & 85,1 & 83,7 \\
\hline
\end{tabular}




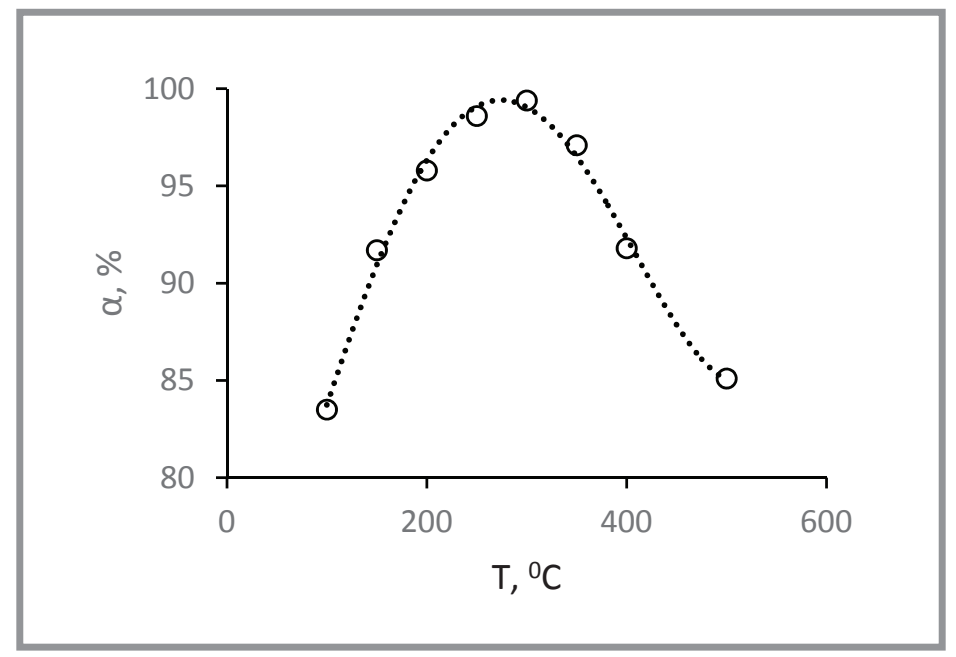

Рuc. 1. Зависимость степени извлечения от температуры обработки образцов сорбента

Анализируя полученные данные, можно сделать заключение в части наибольших сорбционных свойств полученного образца при температуре $250-300^{\circ} \mathrm{C}$. Все образцы различных концентраций диатомита и цеолита были апробированы при разных температурах. Также можно сказать, что имеется зависимость от времени нагрева сорбента и $\mathrm{pH}$ очищаемого раствора. Оптимальные температуры термической обработки сорбента составляют от 2-4 часов, последующий нагрев не ухудшает степень очистки. Полученные данные хорошо колирируются с результатами [23-26].

Известно использование цеолитсодержащего сорбента, обработанного прокаливанием при температуре $250^{\circ} \mathrm{C}$ в течение $2-4$ часов для очистки воды от ионов металлов [27], но недостатком данного изобретения является низкая эффективность сорбента. Также известны и изобретения, где применяется химически модифицированный цеолит $[28,29]$, к недостаткам данных изобретений можно отнести узкий перечень очищаемых элементов, а также низкую эффективность сорбента и высокую дороговизну производства.

Разработанный метод позволяет получать высокую степень очистки при минимальных издержках на подготовку сырья по сравнению с известными методами. Получены оптимально эффективные режимы для производства наноактивированного сорбента представленным методом. 


\section{Библиографический список:}

1. Проблемы загрязнения окружающей среды и токсикологии: Пер. с англ. / Под ред. Дж. Уэра. - М.: Мир, 1993. - 192 с.

2. Телитченко M.M., Остроулов С.A. Введение в проблемы биохимической экологии: биотехнология, сельское хозяйство, охрана среды. - М.: Наука, 1990. 285 c.

3. Черняев А.М., Дальков М.П., Розенберг Г.С. и др. Вода России. Речные бассейны. - Екатеринбург: «АКВА-ПРЕСС», 2000. - 536 с.

4. Виноградов С.С. Экологически безопасное гальваническое производство. - М.: Глобус, 1998. - 302 с.

5. Виноградов С.С. Организация гальванического производства. Оборудование, расчет производства, нормирование. - М.: Глобус, 2005. - 368 с.

6. Фрог Б.Н., Левченко А.П. Водоподготовка. - М.: МГУ, 1996. - 680 с.

7. Алексеев Ю.В. Тяжелые металлы в почвах и растениях. - Л.: Агропромиздат, 1987. - 142c.

8. Lukaszczyk J., Lekawska E., Lunkwitz K., Petzold G. Sorbents for Removal Surfactants from Aqueous Solutions. Surface Modification of Natural Solids to Enhance Sorption Ability // J. Appl. Pol. Sci. - 2004. - № 2. - P. 1510-1515.

9. Wan Ngah W.S., Hanafiah M.A. Removal of heavy metal ions from wastewater by chemically modified plant wastes as adsorbents: A Review // Bioresource. Technol. - 2008. - V. 99. - P. 3935-3948.

10. Unuabonah E.I., Adebowale K.O., Olu-Owolabi B.I. Adsorption of $\mathrm{Pb}$ (II) and Cd (II) from aqueous solutions onto sodium tetraborate-modified Kaolinite clay: Equilibrium and thermodynamic studies // Hydrometallurgy. - 2008. - V. 93. - P. 1-9.

11. Jiang $M$., Wang $Q$., Jin $X$., Chen $Z$. Removal of $\mathrm{Pb}$ (II) from aqueous solution using modified and unmodified kaolinite clay // J. Hazard. Matter. - 2009. - V. 170. P. 332-339.

12. Özdemir G., Yapar S. Adsorption and desorption behavior of copper ions on Namontmorillonite: Effect of rhamnolipids and $\mathrm{pH} / /$ J. Hazard. Matter. - 2009. V. 166. - P. 1307-1313.

13. Xu H., Yang L., Wang P., Liu Y. Kinetic research on the sorption of aqueous lead by synthetic carbonate hydroxyapatite // J. Environ. Manage. - 2008. - V. 86. P. 319-328.

14. Nadeem M., Shabbir M., Abdullah M.A. Sorption of cadmium from aqueous solution by surfactant-modified carbon adsorbents / Chem. Eng. J. - 2009. - V. 148. P. 365-370. 
15. Di Natale F., Erto A., Lancia A., Musmarra D. Experimental and modelling analysis of As(V) ions adsorption on granular activated carbon / / Water. Res. - 2008. V. 42. - P. 2007-2016.

16. Azizian S., Haerifar M., Bashiri H. Adsorption of methyl violet onto granular activated carbon: Equilibrium, kinetics and modeling // Chem. Eng. J. - 2009. V. 146. - P. 36-41.

17. Rao G., Lu C., Su F. Sorption of divalent metal ions from aqueous solution by carbon nanotubes: A Review // Sep. Purif. Technol. - 2007. - V. 58. - P. 224-231.

18. Zhang L., Huang T., Zhang M., Guo X. Studies on the capability and behavior of adsorption of thallium on nano- $\mathrm{Al}_{2} \mathrm{O}_{3} / /$ J. Hazard. Matter. - 2008. - V. 157. P. 352-357.

19. Debnath S., Ghosh U. Nanostructured hydrous titanium(IV) oxide: Synthesis, characterization and Ni (II) adsorption behavior // Chem. Eng. J. - 2009. - V. 152. P. 480-491.

20. Gao Z., Bandosz T., Zhao Z., Han M. Investigation of factors affecting adsorption of transition metals on oxidized carbon nanotubes // J. Hazard. Matter. - 2009. V. 167. - P. 357-365.

21. Лисичкин Г.В. Модифицированные кремнеземы в сорбции, катализе и хроматографии. - М.: Химия, 1986. - 556 с.

22. Лисичкин Г.В., Фадеев А.Ю., Сердан А.А. и др. Химия привитых поверхностных соединений. - М.: Физматлит, 2003. - 589 с.

23. Клилов E.C., Бузаева M.B. Природные сорбенты и комплексоны в очистке сточных вод. - Ульяновск: УлГТУ, 2011. - 201 с.

24. Слесаренко Ф.А. Физико-химические исследования природных сорбентов. Саратов: Мин. просвещения РСФСР, 1968. - 102 с.

25. Халилов Э.Н., Багиров Р.А. Природные цеолиты, их свойства, производство и применение. - Баку-Берлин, 2002. - 347 с.

26. Кельцев Н.В. Основы адсорбционной техники. - Москва: Химия, 1984. - 591с.

27. Патент России № 2111171. Способ абсорбционной очистки воды / Т.П. Конюхова, Т.Н. Чуприна, С.З. Нагаева, Д.А. Кикило, О.А. Михайлова, Г.С. Лучкин, У.Г. Дистанов, Ю.Г. Харисов // 96112598/25, 25.06.1996. 20.05.1998.

28. Патент России № 2184607. Способ получения органоминеральных сорбентов / Н.П. Шапкин // 2000121520/04, 10.08.2000, 10.07.2002.

29. Патент России № 2562495. Способ детоксикации сточных вод, загрязненных солями мышьяка / В.М. Кан, А.С. Коновалов, Д.О. Таран, А.Н. Бобров, М.В. Бутырин, Д.И. Стом // 2013152455А, 10.06.2015, 10.09.2015. 
УВАЖАЕМЫЕ КОЛЛЕГИ!

ПРИ ИСПОЛЬЗОВАНИИ МАТЕРИАЛА ДАННОЙ СТАТЬИ

ПРОСИМ ДЕЛАТЬ БИБЛИОГРАФИЧЕСКУЮ ССЫЛКУ НА НЕЁ:

Малкин П. Очистка сточных вод от ионов тяжелых металлов с помощью наноактивированных комплексов природного цеолита и диатомита // Нанотехнологии в строительстве. - 2018. - Том 10, № 2. - C. 21-41. - DOI: dx.doi. org $/ 10.15828 / 2075-8545-2018-10-2-21-41$.

\section{DEAR COLLEAGUES!}

THE REFERENCE TO THIS PAPER hAS THE FOLLOWING CITATION FORMAT:

Malkin $P$. Wastewater treatment from heavy metal ions using nanoactivated complexes of natural zeolite and diatomite. Nanotehnologii $\mathrm{v}$ stroitel'stve $=$ Nanotechnologies in Construction. 2018, Vol. 10, no. 2, pp. 21-41. DOI: dx.doi. org $/ 10.15828 / 2075-8545-2018-10-2-21-41$. 